\title{
Participation Motivation Scale for E-Sports: The Study of Validity and Reliability (PMSES)
}

\author{
Mehmet GÜL1, Oğuzhan GÜL², Recep Nur UZUN³
}

${ }^{1}$ School of Physical Education and Sports, Sivas Cumhuriyet University, Sivas, Turkey

${ }^{2}$ Faculty of Sports Sciences, Erciyes University, Kayseri, Turkey

${ }^{3}$ Faculty of Yaşar Dogu Sports Sciences, Ondokuz Mayıs University, Samsun, Turkey

Address Correspondence to O. Gül, e-mail: ogulsivas@gmail.com

\begin{abstract}
Electronic sports appeared in the world in the late 1970s and gained popularity in the 2000s. In Turkey, on the other hand, the popularity and the number of players has increased after 2008. In this study, the Participation Motivation Scale for E-Sports (PMSES) was developed in order to evaluate the motivation for participation of those who do E-Sports. The research included 590 participants that play various E-Sports games. The research was designed as the structural equation and mixed model. Within the scope of the structural validity of the scale, exploratory factor analysis (EFA) was carried out in the SPSS 23, and confirmatory factor analysis (CFA) was applied to the measuring instrument in AMOS Software. The Kaiser-Meyer-Olkin (KMO) value was found to be 0.975 and the sample size was found to be sufficient. As a result of the factor analysis applied regarding the validity of the scale, three factors representing $78.847 \%$ of the total variance were obtained. The Cronbach Alpha coefficient was calculated as 0.972 as a result of the reliability analysis of the 22 -item scale. It can be said that the Participation Motivation Scale for E-Sports (PMSES) is a valid and reliable data collection tool that can measure the participation motivation of the individuals who do E-Sports.
\end{abstract}

Keywords: Electronic Sports, Participation Motivation, Structural Equation Model, Mixed Model, Factor Analysis

\section{INTRODUCTION}

Motivation, which is also called the motive psychology, is the driving force behind the movements of the individual (31). Besides, motivation means an individual's awareness of their wishes and needs and taking action to realize these. There are some factors that affect motivation positively or negatively (8). Depending on the positive or negative factors in question and the nature and intensity of the motives in our lives, all our behaviors gain direction or change continuously (6). For instance, athlete conducts various behaviors to be successful and to achieve his/her goals (4). It is a fact that the inherent competitiveness of sports is generally considered to stem from motivation (24).
Therefore, it is quite clear that motivation is very important especially in sports (28). For this reason, motivation is one of the basic subjects of sports psychology and it has an important role in explaining behaviors in the sports environment. In particular, the efforts to develop explanatory approaches related to reasons for participating in a sports activity, maintaining participation, and quitting are noteworthy (12). If we think that the main motives that affect the participation of individuals in sports activities affect the continuation and termination of participation; determining these motives is going to be an important step in increasing participation. 
Electronic sports are a sports branch in which amateur-professional players compete with each other through computer or game consoles. Computer systems mediate the games of players and teams. The game is played on a virtual platform. In other words, the computer system is as much important for Electronic sports as stadiums are for football.

Electronic sports games have become a thriving phenomenon via online media, the world's fastest growing media type. Attracting 70 million spectators in 2013, this sports branch is estimated to have attracted 400 million spectators in 2016 (22; 33).

Some people in the world advocate that electronic sports are not a kind of sports. The main reason for this idea is that electronic athletes do not compete with any physical activity. It is a common belief that sports cannot be done by sitting on an armchair and that there must be physical activity in the sports. However, there is also a physical activity in electronic sports. Athletes are required to optimize their reflexes, brain functions, and handeye coordination in order to be successful in the games they perform (34). In addition to this, the competition, teams, fans, sports halls, products etc. necessitate E-Sports being considered a sports branch $(10 ; 27)$.

As in non-electronic sports, there are various branches in electronic sports as well. Electronic sports are divided into FPS (First-person shooter), RTS (real-time strategy), Sport-Racing Games, MOBA (Massively Online Battle Arena) and other esports games (World of Tanks, Hearthstone, etc.). Virtual versions of traditional sports games are also performed as electronic sports $(13 ; 27)$.

\section{First-Person Shooter Games}

First-person shooter games are games that can be played both individually and as a team. The players direct the digital game environment through the virtual characters they create. In this type of game, the age limit is generally determined to be +18 . These game types offer a wide range of areas to players from realistic contents like military simulation to fun, exciting and fantastic worlds. The qualifications required to be successful in this type of games for players are reflexes, making quick judgments and team management (E.g. Overwatch, Counter-Strike, Quake, Zula, Crossfire) (27).

The companies operating in Turkey for major games in this genre are as follow:

> Point Blank (nFinity Games, S. KOREA)

$>$ Wolfteam (Netmarble, S. KOREA)

$>$ Zula (In Game Group, Madbyte Games)

> Counter Strike Global Offensive (Valve, USA)

$>$ Overwatch (Blizzard Entertainment, USA)

\section{Real-Time Strategy}

These games are played individually most of the time and sometimes are played as a team. In these games, the players build an army by making use of the available resources. With their army in the virtual environment, the players try to defeat their rivals' armies (E.g. Star Craft) considering many factors simultaneously (timing, land conditions, production timing, and resource management) (27).

\section{Sport-Racing Games}

It is an adapted form of traditional sports in the virtual environment. E-Sports companies with the licensing agreements with various sports federations have made famous sports clubs and athletes available to the virtual platform with their realistic features. For instance, a player can choose the latest squads and then play with teams such as Manchester United, Real Madrid or Galatasaray. Virtual motorsports are also considered within this type of game (E.g. Pro Evolution Soccer, FIFA, UFC, Track-mania, Fight-Night, NBA 2K17) (27).

\section{MOBA (Massively Online Battle Arena)}

This type of games is played by trying to destroy each other's energy sources on a map of three main roads between two rival teams, usually consisting of five people (27).

It is an electronic sports branch that has a massive group of players, and that is the most popular E-Sports branch not only in Turkey but also in the world today. The fact that the brands such as DOTA II and League of Legends, which can be run on any computer, can be played in fast as a team, has made it easier for such games to become 
widespread. Thanks to the offices set up and the investments made by Riot Games in 2012, electronic sports have developed more rapidly in Turkey (27).

The companies operating in Turkey for major games in this genre are as follow:

$>$ League of Legends (Riot Games, China-USA, Turkey Office available)

Strike of Kings (Tencent, China)

$>$ DOTA II (Valve, USA)

> MMORPG: (Massively Multiplayer Online RolePlaying Game) Role-playing games that can be played connecting to any server (27).

\section{Other E-Sports Games}

Popular games out of the category are:

> Hearthstone: The card game that takes the popular game characters as the theme. (Not to be confused with gambling and betting games) (Blizzard, USA) (27).

$>$ World of Tanks: An action and strategy game that can be played individually or as a team, on virtual maps with tanks that belong to World War II times. (Wargaming, White Russia) (27).

Electronic sports offer an environment where people from the far end of the world meet via the internet or by coming from different parts of the world to meet people in big organizations (3). For this reason, E-Sports spectators and followers show an increase over the years. Award-winning tournaments started to show interest in competitive games increased (19). As a matter of fact, electronic sports have reached a huge budget of $\$ 905$ million and it is predicted to increase to a budget of $\$ 1.4$ billion in the 2020s (23). Therefore, it is important to make a validity and reliability study of Participation Motivation Scale for E-Sports (PMSES) for these sports, which seems to be in the life of many individuals in this generation and the next generations.

\section{MATERIAL and METHOD}

In this section, information about the model used in the research, the research group and the development process of the measuring instrument are given.

\section{Research Model}

In this study, the mixed model was used to develop a valid and reliable measuring instrument in order to measure the participation motivation of the individuals in electronic sports. Mixed studies are the studies where the qualitative and quantitative data are analyzed in a single study and the different data sources are inter-converted and verified (20).

\section{Research Group}

Individuals that are engaged in electronic sports in different branches participated in this study. In the study, the criterion sampling method (25) was used as one of the purposeful sampling methods which provide in-depth research opportunity. In the criterion sampling method, the researcher can set criteria that meet a set of predetermined values (35).The criterion of being actively engaged in various branches of E-sports during at least one year was determined for the athletes participating in the research. (Such as Zula, LoL, Cs-Go, CALL of DUTY, PubG, Wolfteam, FIFA-PES, Formula 1, WORLD of TANKS, etc.) In this context, a total of 590 people that competed in one or several various sports branches participated in the research(365 Zula, 39 LoL, 69 Cs-Go, 28 CALL of DUTY, 56 PubG, 219 Wolfteam, 65 FIFA-PES, 6 Formula 1, 10 WORLD of TANKS). Some researchers state that the size of the study group must be at least five times the number of items in the scale $(1 ; 5 ; 26 ; 30 ; 32)$. Accordingly, it can be said that the research group, to which the 74item scale form is administrated, has a sufficient number of participants for the statistical procedures. $8.8 \%(\mathrm{n}=52)$ of the participants were female and $91.2 \%(n=538)$ of them were male.

\section{Development Process of Measurement Instrument}

In this section, the following processes were followed in order to determine the levels of e-sports participation motivation of the individuals engaged in electronic sports.

\section{Developing an Item Pool}

When developing the item pool, the studies on e-sports concept and accessible studies were reviewed. The body of literature was examined paying particular attention to the studies regarding 
the motivation level on E-Sports concept. When the literature about e-sports was examined, we found that two scales are available: Kari and Karhulahti's (17) 7-item scale on the physical training in E-Sports and the 12-item scale called "E-Sports Motivation Scale: League of Legends", which was developed by Sun as a part of M.A. thesis (29).

\section{Items from the Literature}

In the first stage of developing the item pool, the scientific studies about E-Sport concept and also blog sites where e-athletes shared their views were examined. On the other hand, E-sports studies on motivation in sports, sports media, sports tourism and sports economy related to the concept of ESports were examined.

\section{Items based on Focus Group Studies}

In the second phase of developing the item pool, two focus group meetings were held. The first focus group meeting consisted of seven men between the ages of 20-35. The participants were university graduate, graduate students and employees. The second focus group meeting was held with a group of eleven students. Firstly, the concept of E-Sports was tried to be expressed clearly to the participants. The concept of E-Sports, its definition and its applications were explained and the participants were fully informed about the concept. The games that are within the scope of electronic sports were mentioned (Zula, LoL, Cs-Go, CALL of DUTY, PubG, Wolfteam, FIFA-PES, Formula 1, WORLD of TANKS, Clash Royal etc.). The participants were then asked for their opinions about the E-Sports games and the E-Sports concept. According to examples given, the opinions of the participants about the concept of E-Sports were asked to find out their attitudes towards the ESports concept.

\section{Expert View}

In the final stage of developing the item pool, the academicians who were specialized in the areas of Sports Management, Sports Economics, and Sports-Media were interviewed. Their opinions on E-Sports and their ideas about the adaptability of for the scale about the E-Sports concept were taken into consideration. The items gathered in line with the views of academicians were arranged, resulting in a large item pool consisting of 74 questions. Finally, the 74-question item pool was administrated to the individuals that are actively engaged in E-Sports, and statistical evaluations of the scale were made.

\section{RESULTS}

\section{Findings of Exploratory Factor Analysis (EFA)}

In order to determine the construct validity of the scale, explanatory factor analysis was conducted.

Table 1. Examination of the Suitability of Data for Factor Analysis

\begin{tabular}{|c|c|c|}
\hline $\begin{array}{l}\text { Kaiser-Meyer-Olkin } \\
\text { (KMO) Sample }\end{array}$ & \multicolumn{2}{|c|}{0.975} \\
\hline \multirow{3}{*}{ Bartlett's Test } & Chi-square & 15897.030 \\
\hline & S.d & 231 \\
\hline & $\begin{array}{c}\mathrm{p} \\
(\mathrm{p}<0.001)\end{array}$ & 0.000 \\
\hline
\end{tabular}

Since the KMO coefficient is 0.975 , the sample size in the study is sufficient (Table 1).

Since there is significance level (probability) in consequence of Bartlett's Test of Sphericity, the data meets the assumption of multiple normal distributions (1) and confirms the feasibility of factor analysis.

The communality is the variance value that a variable share with other variables, and it is required that each variable takes values between 1 and 0.5 (21). Communality values are given in Table 2 (below). 


\begin{tabular}{cccc}
\hline \multicolumn{4}{l}{ Table 2. Communality Values for the Items on the Scale } \\
\hline Questions & $\begin{array}{c}\text { Communality } \\
\text { Value }\end{array}$ & Questions & $\begin{array}{c}\text { Communality } \\
\text { Value }\end{array}$ \\
\hline $\mathrm{s} 69$ & .925 & $\mathrm{~s} 71$ & .897 \\
\hline $\mathrm{s} 45$ & .917 & $\mathrm{~s} 50$ & .890 \\
\hline $\mathrm{s} 59$ & .916 & $\mathrm{~s} 66$ & .744 \\
\hline $\mathrm{s} 53$ & .915 & $\mathrm{~s} 49$ & .724 \\
\hline $\mathrm{s} 39$ & .915 & $\mathrm{~s} 23$ & .711 \\
\hline $\mathrm{s} 74$ & .910 & $\mathrm{~s} 16$ & .697 \\
\hline $\mathrm{s} 46$ & .905 & $\mathrm{~s} 63$ & .688 \\
\hline $\mathrm{s} 54$ & .904 & $\mathrm{~s} 10$ & .661 \\
\hline $\mathrm{s} 48$ & .904 & $\mathrm{~s} 55$ & .571 \\
\hline $\mathrm{s} 61$ & .904 & $\mathrm{~s} 7$ & .523 \\
\hline $\mathrm{s} 68$ & .901 & $\mathrm{~s} 9$ & .523 \\
\hline
\end{tabular}

As a result of the exploratory factor analysis applied to 22 items remaining in the scale, a three-factor structure emerged (Table 2). The resultant factors of the analysis and the related findings are given in Table 3.

\begin{tabular}{|c|c|c|c|c|c|}
\hline $\begin{array}{l}\text { Sub-dimension of the } \\
\text { Scale }\end{array}$ & Items & Factor Loading & Eigenvalues & $\begin{array}{l}\text { Variance } \\
(\%)\end{array}$ & $\begin{array}{l}\text { Cumulative } \\
\text { Varyans (\%) }\end{array}$ \\
\hline \multirow{13}{*}{$\begin{array}{l}\text { Intrinsic Motivation } \\
\text { for Knowing and Achieving }\end{array}$} & s53 & .893 & \multirow{13}{*}{14.505} & \multirow{13}{*}{65.931} & \multirow{13}{*}{65.931} \\
\hline & s69 & .884 & & & \\
\hline & s71 & .878 & & & \\
\hline & s59 & .871 & & & \\
\hline & s74 & .871 & & & \\
\hline & s68 & .860 & & & \\
\hline & $\mathrm{s} 45$ & .852 & & & \\
\hline & $\mathrm{s} 48$ & .843 & & & \\
\hline & s39 & .848 & & & \\
\hline & s46 & .831 & & & \\
\hline & s54 & .831 & & & \\
\hline & s61 & .815 & & & \\
\hline & s50 & .802 & & & \\
\hline \multirow{5}{*}{ Extrinsic Regulation } & s9 & .701 & \multirow{5}{*}{1.839} & \multirow{5}{*}{8.361} & \multirow{5}{*}{74.292} \\
\hline & s16 & .655 & & & \\
\hline & s10 & .664 & & & \\
\hline & s7 & .761 & & & \\
\hline & s23 & .604 & & & \\
\hline \multirow{4}{*}{ Identification } & s55 & .828 & \multirow{4}{*}{1.002} & \multirow{4}{*}{4.555} & \multirow{4}{*}{78.847} \\
\hline & $s 63$ & .734 & & & \\
\hline & s66 & .733 & & & \\
\hline & s49 & .677 & & & \\
\hline
\end{tabular}

When the results of the exploratory factor analysis of the scale in Table 3 are examined, it is seen that there are 3 factors with an eigenvalue greater than 1 . The variance explained by the first factor is 65.931, the variance explained by the second factor is 8.361 , and the variance explained by the third factor is 4.555 . The total variance explained is $78.847 \%$. The total variance explained is sufficient as it exceeds $60 \%$ (Table 3). 
Table 4. Rotated Components Matrix for Factor Structure of the Scale

\begin{tabular}{|c|c|c|c|}
\hline \multirow{2}{*}{ Items } & \multicolumn{3}{|c|}{ Components } \\
\hline & 1 & 2 & 3 \\
\hline s53 & .893 & & \\
\hline s69 & .884 & & \\
\hline s71 & .878 & & \\
\hline s59 & .871 & & \\
\hline s74 & .871 & & \\
\hline s68 & .860 & & \\
\hline s45 & .852 & & \\
\hline s48 & .843 & & \\
\hline s39 & .848 & & \\
\hline $\mathrm{s} 46$ & .831 & & \\
\hline s54 & .831 & & \\
\hline s61 & .815 & & \\
\hline s50 & .802 & & \\
\hline s9 & & .701 & \\
\hline s16 & & .655 & \\
\hline s10 & & .664 & \\
\hline s7 & & .761 & \\
\hline $\mathrm{s} 23$ & & .604 & \\
\hline s55 & & & .828 \\
\hline s63 & & & .734 \\
\hline s66 & & & .733 \\
\hline
\end{tabular}

In order to do confirmatory factor analysis, there must be at least three variables measuring each latent variable. For this reason, it was ensured that there were at least three variables under each factor. In addition, the items which were either overlapping or had low communality values in two or more factors were excluded from the scale and thus a 22item scale was obtained. The results of the analysis show that the scale has construct validity (Table 4 ).

\section{Naming the Factors (Nomenclature)}

Since the main reason for the exploratory factor analysis is to reduce a large number of variables to a smaller number of factors, these factors which emerged must be named. This naming process is made in line with the common features of the variables in the factor (21).

The items belonging to the 3 factors obtained from the exploratory factor analysis and the appropriate nomenclature for these items are given below (Table 5). 


\begin{tabular}{|c|c|}
\hline Item & FACTORS \\
\hline \multicolumn{2}{|c|}{ First Factor: Intrinsic Motivation for Knowing and Achieving } \\
\hline s53 & It gives me pleasure to discover my talents in E-Sports. \\
\hline s69 & The experiences I discovered in E-Sports give me pleasure. \\
\hline s71 & It makes me happy to show my skills to others in E-Sports. \\
\hline s59 & The competitive environment in E-Sports excites me. \\
\hline s74 & I enjoy the techniques and tactics in E-Sports. \\
\hline s68 & I like to follow professional players and teams in E-Sports. \\
\hline s45 & E-Sports is a passion for me. \\
\hline s48 & I am having a good time with my friends in E-Sports platform. \\
\hline s39 & I think E-sports is exciting in terms of content. \\
\hline s46 & I value the friendship relationships I have established in E-Sports. \\
\hline s54 & I enjoy doing E-Sports in my spare time. \\
\hline s61 & I like to know different people and cultures by doing E-Sports. \\
\hline s50 & I enjoy making friends in the E-Sports platform. \\
\hline \multicolumn{2}{|c|}{ Second Factor: Extrinsic Regulation } \\
\hline s9 & My friends' passion for E-Sports led me to E-Sports. \\
\hline s16 & I think E-Sports has positive effects on my education life. \\
\hline s10 & I feel incomplete unless I do E-Sports. \\
\hline s7 & My family supports my interest in E-Sports and my being an E-Sports athlete. \\
\hline s23 & I got positive feedback from my environment after I started to do E-Sports. \\
\hline \multicolumn{2}{|c|}{ Third Factor: Identification } \\
\hline s55 & I feel more tired while doing E-Sports. \\
\hline s63 & I'm playing E-sports to invest for the future. \\
\hline s66 & I think E-Sport is important for my health. \\
\hline s49 & I think doing e-sports is enough for physical activity. \\
\hline
\end{tabular}

Intrinsic Motivation for Knowing and Achieving: This title is related to various structures such as explanation, curiosity, learning objectives, competence, task orientation, learning, knowing and understanding. It means that the person participates in the activity as he/she enjoys the pleasure of personal satisfaction while trying to learn, achieve, explain and understand something new (16).

Extrinsic Regulation: It is stated that the behaviors of the individual are controlled by external sources and the reasons for the participation of the person in the sport originate from the desire of earning respect and being rewarded, besides the social pressure (16).
Identification: It is stated that the individual participates in the activity because

he/she considers the behavior as important, and believes that their participation contributes to their personal development (16).

\section{The Findings of the Confirmatory Factor Analysis}

Confirmatory factor analysis was carried out in order to examine the goodness of fit and construct validity of the structure, which was determined to be composed of 3 factors by exploratory factor analysis and the following results were obtained.

When testing the compatibility between the model and the data, it may be preferable to use some or all of the goodness of fit tests (20). However, there is no consensus in the literature regarding which of this goodness of fit statistics should be used (15). 
Table 6. Fit Indices used in Confirmatory Factor Analysis

\begin{tabular}{lccc}
\hline $\begin{array}{c}\text { Model } \\
\text { Compatibility Criteria }\end{array}$ & Goodness of Fit & Acceptable Fit & Obtained Value \\
\hline CMIN/SD & $\chi / \mathrm{sd} \leq 3$ & $\chi / \mathrm{sd} \leq 5$ & 4.124 \\
\hline TLI (NNFI) & $0.95 \leq \mathrm{NNFI}$ & $0.90 \leq \mathrm{NNFI}$ & .954 \\
\hline IFI & $0.95 \leq \mathrm{IFI}$ & $0.90 \leq \mathrm{IFI}$ & .959 \\
\hline CFI & $0.97 \leq \mathrm{CFI}$ & $0.95 \leq \mathrm{CFI}$ & .959 \\
\hline RMSEA & RMSEA $\leq 0.05$ & RMSEA $\leq 0.08$ & .073 \\
\hline RMR & & Residual Baseline Fit Indices & .055 \\
\hline GFI & $0<$ RMR $\leq 0.05$ & $0<$ RMR $\leq 0.08$ & .883 \\
\hline AGFI & $0.90 \leq \mathrm{GFI}$ & Absolute Fit Indices & .857 \\
\hline
\end{tabular}

As it can be seen in Table $6, \quad \chi^{2} / \mathrm{df}=4.124$ Regression Weights of the Model $5 ; 0.912<$ IFI $=0.913 ; \quad 0.954<T L I=0.955 ; 0.959<\quad$ The following table shows the regression weights. CFI 0.960; RMSEA $=0.073<0.08 ; \quad$ RMR $=0.055$ the regression values show the observed variables' 0.08 the model according to fit values shows apower of estimation about the latent variables, in other acceptable fit with the data. Therefore, the validity ofords, factor loadings. Since the " $p$ " value for each the 3-factor structure revealed by binary relation below is less than 0.05, the factor

exploratory factor analysis was confirmed blyadings are important. The factor loadings that were confirmatory factor analysis as well. In other words, thfound important indicate that the items have been scale can be used to measure the participation levels pfroperly loaded on the factors. electronic sports athletes in electronic sports (Table 6).

\begin{tabular}{|c|c|c|c|c|}
\hline & Estimate & S.E (Standard Error) & C.R. (Critical Ratio) & $\mathrm{P}$ \\
\hline $\mathrm{s} 50 \leftarrow \mathrm{F} 1$ & 1.000 & & & \\
\hline $\mathrm{s} 61 \leftarrow \mathrm{F} 1$ & 1.011 & .030 & 34.146 & $* * *$ \\
\hline $\mathrm{s} 54 \leftarrow \mathrm{F} 1$ & 1.035 & .030 & 34.968 & $* * *$ \\
\hline $\mathrm{s} 46 \leftarrow \mathrm{F} 1$ & 1.053 & .030 & 34.731 & $* * *$ \\
\hline $\mathrm{s} 39 \leftarrow \mathrm{F} 1$ & 1.059 & .029 & 36.421 & $* * *$ \\
\hline $\mathrm{s} 48 \leftarrow \mathrm{F} 1$ & 1.025 & .029 & 35.003 & $* * *$ \\
\hline $\mathrm{s} 45 \leftarrow \mathrm{F} 1$ & 1.076 & .030 & 36.453 & $* * *$ \\
\hline $\mathrm{s} 68 \leftarrow \mathrm{F} 1$ & 1.043 & .029 & 35.703 & $* * *$ \\
\hline $\mathrm{s} 74 \leftarrow \mathrm{F} 1$ & 1.048 & .028 & 36.831 & $* * *$ \\
\hline $\mathrm{s} 59 \leftarrow \mathrm{F} 1$ & 1.067 & .028 & 37.504 & $* * *$ \\
\hline $\mathrm{s} 71 \leftarrow \mathrm{F} 1$ & 1.048 & .029 & 36.064 & $* * *$ \\
\hline $\mathrm{s} 69 \leftarrow \mathrm{F} 1$ & 1.084 & .028 & 38.729 & $* * *$ \\
\hline $\mathrm{s} 53 \leftarrow \mathrm{F} 1$ & 1.086 & .028 & 38.303 & $* * *$ \\
\hline $\mathrm{s} 23 \leftarrow \mathrm{F} 2$ & 1.000 & & & \\
\hline $\mathrm{s} 7 \leftarrow \mathrm{F} 2$ & .881 & .056 & 15.603 & $* * *$ \\
\hline $\mathrm{s} 10 \leftarrow \mathrm{F} 2$ & .989 & .055 & 18.114 & $* * *$ \\
\hline $\mathrm{s} 16 \leftarrow \mathrm{F} 2$ & 1.038 & .051 & 20.513 & $* * *$ \\
\hline $\mathrm{s} 9 \leftarrow \mathrm{F} 2$ & .856 & .061 & 13.993 & $* * *$ \\
\hline $\mathrm{s} 49 \leftarrow \mathrm{F} 3$ & 1.000 & & & \\
\hline $\mathrm{s} 66 \leftarrow \mathrm{F} 3$ & 1.061 & .039 & 27.357 & $* * *$ \\
\hline
\end{tabular}


Table 7. Regression Weights Related to the Model

\begin{tabular}{rcccc}
\hline & Estimate & S.E (Standard Error) & C.R. (Critical Ratio) & P \\
\hline $\mathrm{s} 63 \leftarrow \mathrm{F} 3$ & .954 & .043 & 22.306 & $* * *$ \\
\hline $\mathrm{s} 55 \leftarrow \mathrm{F} 3$ & .926 & .047 & & \\
\hline$* * * * \mathrm{p}<0.001$ & & & & \\
\hline
\end{tabular}

Another important case in confirmatory coefficients. The regression values show the factor analysis is the estimation values of observed variables' power of estimation about regression weights. The following table the latent variables, in other words, factor provides standardized regression weights loadings (Table 7).

\begin{tabular}{cccc}
\hline Table 8. Standardized Regression Coefficients & & \\
\hline Relation & Estimate & Relation & Estimate \\
\hline $\mathrm{S} 50 \leftarrow \mathrm{F} 1$ & .887 & $\mathrm{~S} 69 \leftarrow \mathrm{F} 1$ & .946 \\
\hline $\mathrm{S} 61 \leftarrow \mathrm{F} 1$ & .903 & $\mathrm{~S} 53 \leftarrow \mathrm{F} 1$ & .943 \\
\hline $\mathrm{S} 54 \leftarrow \mathrm{F} 1$ & .911 & $\mathrm{~S} 23 \leftarrow \mathrm{F} 2$ & .790 \\
\hline $\mathrm{S} 46 \leftarrow \mathrm{F} 1$ & $\mathrm{~S} 7 \leftarrow \mathrm{F} 2$ & .636 \\
\hline $\mathrm{S} 39 \leftarrow \mathrm{F} 1$ & .909 & $\mathrm{~S} 10 \leftarrow \mathrm{F} 2$ & .723 \\
\hline $\mathrm{S} 48 \leftarrow \mathrm{F} 1$ & $\mathrm{~S} 16 \leftarrow \mathrm{F} 2$ & .804 \\
\hline $\mathrm{S} 45 \leftarrow \mathrm{F} 1$ & .926 & $\mathrm{~S} 23 \leftarrow \mathrm{F} 2$ & .578 \\
\hline $\mathrm{S} 68 \leftarrow \mathrm{F} 1$ & .912 & $\mathrm{~S} 49 \leftarrow \mathrm{F} 3$ & .838 \\
\hline $\mathrm{S} 74 \leftarrow \mathrm{F} 1$ & .926 & $\mathrm{~s} 66 \leftarrow \mathrm{F} 3$ & .904 \\
\hline $\mathrm{S} 59 \leftarrow \mathrm{F} 1$ & .919 & $\mathrm{~s} 63 \leftarrow \mathrm{F} 3$ & .786 \\
\hline $\mathrm{S} 71 \leftarrow \mathrm{F} 1$ & .930 & $\mathrm{~S} 55 \leftarrow \mathrm{F} 3$ & .717
\end{tabular}


The AMOS diagram of the model obtained from the confirmatory factor analysis is given in Figure 1.

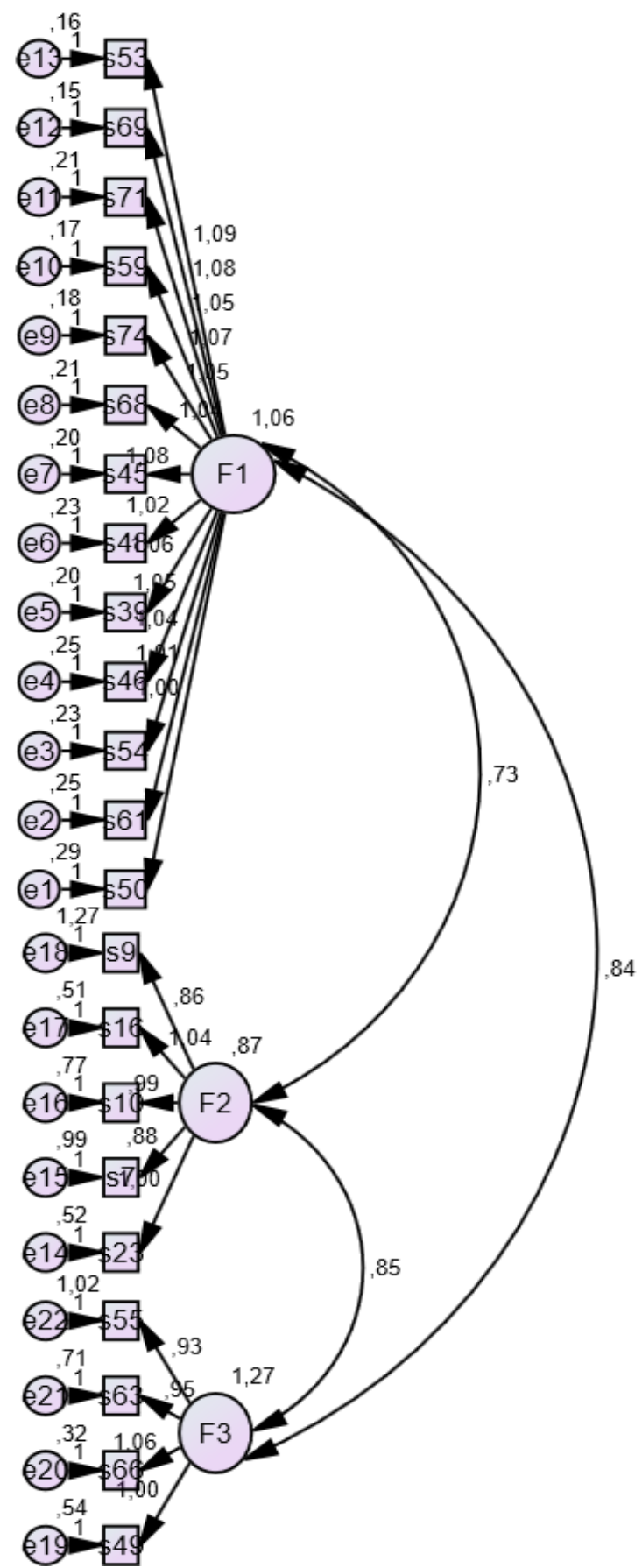

Figure 1. AMOS Diagram of the Model

\section{Normality, Reliability and Validity of Data}

The fact that the significance value is found below 0.01 in the wake of the Bartlett Test of Sphericity indicates that multiple normal distribution assumptions of the data are provided $(1 ; 11)$.

In order to analyze the construct validity of the data, exploratory factor analysis was carried out initially, and then confirmatory factor analysis was used for the discriminant validity (7). Internal consistency analysis (ICA) was also performed. One of the main assumptions in the Likert-type scale development studies is that there is a monotonic relationship between the attitude to be measured and each item in the scale. In other words, there is an assumption that each item basically measures the same attitude (30). For this reason, it is appropriate to use Cronbach's alpha, which is accepted as the internal consistency 
measure (criterion) in order to determine the reliability level when developing a Likert-type scale. The Cronbach's alpha (coefficient a) is between 0 and 1 , and the higher the coefficient $a$, the more the items in the scale are considered to be consistent, which also means that they measure the elements of the same feature (32).

The reliability levels according to Cronbach's alpha values were given below.

$>$ In a condition of $0.00 \leq \alpha<0.40$ the scale has no reliability,

$>$ In a condition of $0.40 \leq \alpha<0.60$ the scale has low reliability,

$>$ In a condition of $0.60 \leq \alpha<0.80$ the scale is quite reliable,

$>$ In a condition of $0.80 \leq \alpha<1.00$ the scale is highly reliable (32).

The internal consistency of the scale is given in table 9 below, both as factors and as the whole of the scale.

Table 9. Internal Consistency Coefficients of the Scale

\begin{tabular}{|c|c|c|}
\hline Factors & Item Numbers & $\begin{array}{l}\text { Cronbach's } \\
\text { Alpha Internal } \\
\text { Consistency } \\
\text { Coefficient }\end{array}$ \\
\hline $\begin{array}{l}\text { (F1) Intrinsic } \\
\text { Motivation for } \\
\text { Knowing and } \\
\text { Achieving }\end{array}$ & $\begin{array}{l}\text { s39, s45, s46, s48, } \\
\text { s50, s53, s54, s59, } \\
\text { s61, s68, s69, s71 } \\
\text { and s74 }\end{array}$ & .986 \\
\hline $\begin{array}{l}\text { (F2) Extrinsic } \\
\text { Regulation }\end{array}$ & $\begin{array}{c}\text { s7, s9, s10, s16 and } \\
\text { s23 }\end{array}$ & .833 \\
\hline (F3) Identification & $\begin{array}{c}\text { s49, s55, s63 and } \\
\text { s66 }\end{array}$ & .885 \\
\hline
\end{tabular}

According to the data in Table 9, since the reliability levels of all factors were found to be [F1 $\alpha=0.986$; F2 $\alpha=0.833$; F3 $\alpha=0.885$ ], of all items was $[\alpha=0.971-0.969]$ and the Cronbach's Alpha Internal Consistency Coefficient of the whole 22item scale was $[\alpha=0.972]$, it is found to be highly reliable (Table 9).

\section{CONCLUSION}

In this study, a valid and reliable measurement tool has been developed in order to measure the participation motivation of the individuals in esports.
In order to develop the measuring instrument, a 74-item pool has been created after the literature review, the focus group studies and taking expert advice.

In order to ensure the construct validity of the Participation Motivation Scale for E-Sports in the SPSS 23, alpha factor analysis (AFA), and confirmatory factor analysis (CFA) was performed in AMOS Software. For the exploratory factor analysis, The Kaiser-Meyer-Olkin coefficient and Barlett's test were applied, the KMO coefficient value was found to be 0.975 and with these results, the suitability of the data for factor analysis has been demonstrated. As a result of EFA, 22 items explaining $78.847 \%$ of the total variance were obtained. As a result of the rotated principal components analysis, a structure consisting of 3 sub-dimensions was obtained. These are "Intrinsic Motivation for Knowing and Achieving", "Extrinsic Regulation" and "Identification" factors. In the results of the confirmatory factor analysis of the Participation Motivation Scale for Electronic Sports (PMSES), the fit index values related to PMSES were found as: $\chi^{2} / \mathrm{df}=4.124<5 ; 0.912<\mathrm{IFI}=$ $0.913 ; 0.954<T L I=0.955 ; \quad 0.959<C F I=0.960$; RMSEA $=0.073<0.08 ; \quad$ RMR $=0.055<0.08$. According to the range of acceptable variance and good variance, three sub-dimensions obtained from the confirmatory factor analysis of the Participation Motivation Scale for E-Sports (PMSES) seem to have adequate fit indices. In order to determine whether the items in the sub-dimensions of the scale measure the desired feature, the test correlations of the items and the lower $27 \%$ and higher $27 \%$ group were compared. As a result of these analyses, it was detected that the items in the scale were highly discriminant. It is seen that the item-total correlation values ranged between 0.604 and 0.893 . These results show that each item is fully compatible with the scale. In order to test the reliability of the scale, Cronbach's Alpha internal consistency coefficient was calculated, thus the internal consistency coefficient in the scale was found to be 0.972 . The coefficient was found to be 0.986 in "intrinsic motivation for knowing and achieving" sub-dimension, it was found to be 0.833 
in "extrinsic regulation" sub-dimension, and it was found to be 0.885 in the "identification" subdimension. This value is higher than 0.60 , the lowest acceptable reliability in the literature (18; 14). Alpar (2) stated that the scales that have a Cronbach's Alpha internal consistency coefficient between 0.60 and 0.80 can be called reliable. In this context, based on the reliability analysis of the current scale, the scale and its sub-dimensions have

\section{REFERENCES}

1. Akgül, A., \& Çevik, O. İstatiksel Analiz Teknikleri, SPSS'te İşletme Yönetimi Uygulamaları. Emek Ofset, Ankara/ Türkiye. 2003.

2. Alpar, R. Spor bilimlerinde uygulamalı istatistik. Nobel Yayınları, Ankara/ Türkiye, 2006.

3. Argan, M., Özer, A. \& Akın, E. Elektronik Spor: Türkiye'deki Siber Sporcuların Tutum ve Davranışları. Spor Yönetimi ve Bilgi Teknolojileri Dergisi, 2006; 1(2), 1306-4371.

4. Arkonaç S. A. Psikolojide zihin süreçleri bilimi. Alfa Yayınları, Ankara 1998.

5. Balcı, A. Sosyal Bilimlerde Araştırma Yöntem Teknik ve İlkeler. Pegem-Yayınları. Ankara/ Türkiye, 2005.

6. Baştuğ G. Sporda psikolojik motivasyon faktörü olarak ödül ve cezanın cinsiyet ve spora başlama yaşı değişkenine göre incelenmesi. Yüksek Lisans Tezi, Selçuk Üniversitesi Sağlık Bilimleri Enstitüsü. Konya, 2002.

7. Bollen, K. A. Structural Equations with Latent Variables. New York: John Wiley \& Sons. Journal of Korean Academy of Nursing, 1989; 29(5).

8. Can Y, Güven H, Soyer F, Demirel M, Bayansalduz M. \& Şahin K. Elit taekwondo sporcularında aile antrenör, kulüp desteği ve başarı motivasyonu arasındaki ilişkinin incelenmesi. Uluslararası İnsan Bilimleri Dergisi, 2009; 6(2): 240-252.

9. Creswell, J. W., \& Creswell, J. D. Research design: Qualitative, quantitative, and mixed methods approach. 4. Edition, Sage publications, 2017.

10. Gençlik Spor Bakanlığı. E-Spor Raporu. Nisan 2018 tarihinde

http://www.gsb.gov.tr/HaberDetaylari/1/138762/genclikve-spor-bakanligindan-e-spor-raporu.aspx adresinden alınmıştır, 2018.

11. Hair, J. F., Anderson R. E., Tahtam R. L. \& Black W. C. Multivariate Data Analysis. Prentice Hall International Inc., New Jersey, 1998.

12. Hardy, L., Jones, J. G., \& Gould, D. Understanding psychological preparation for sport: Theory and practice of elite performers. John Wiley \& SonsInc, 1996.

13. Hamari, J., \& Sjöblom, M. What is Esports and Why do People Watch it?. Internet Research. 2017. 27(2), 211-232.

14. Highlen, P. S., \& Bennett, B. B. Elite divers and wrestlers: A comparison between open-and closed-skill athletes. Journal of sport psychology, 1983; 5(4), 390-409.

15. İlhan, M. \& Çetin B. Lisrel ve Amos Programları Kullanılarak Gerçekleştirilen Yapısal Eşitlik Modeli (YEM) Analizlerine İlişkin Sonuçların Karşılaştırılması. Eğitimde ve Psikolojide Ölçme ve Değerlendirme Dergisi, $2014 ; 5(2), 26-42$. been proven to be highly reliable. As a result, PMSES can be defined as a valid and reliable measurement tool for determining the source of motivations of individuals participating in E-Sports by playing games such as Zula, LoL, Cs-Go, CALL of DUTY, PubG, Wolfteam, FIFA-PES, Formula 1, WORLD of TANKS etc.

16. Kazak, Z. Sporda Güdülenme Ölçeği SGÖ'nin Türk Sporcuları İçin Güvenirlik ve Geçerlik Çalışması. Hacettepe Üniversitesi Spor Bilimleri Dergisi, 2004; 15(4), 191-206.

17. Kari, T. \& Karhulahti, V. M. Do E-Athletes Move: A Study on Training and Physical Exercise in Elite E-Sports. International Journal of Gaming and Computer-Mediated Simulations (IJGCMS), 2016;. 8(4), 53-66.

18. Klint, K. A. \& Weiss, M. R. Perceived Com-Petence and Motives for Participating in Youth Sports: A Test of Harter's Competence Motivation Theory. Journal of sport Psychology, 1987; 9(1), 55-65.

19. Kocadağ, M. Elektronik Spor Kariyeri ve Eğitim. Doğu Anadolu Sosyal Bilimlerde Eğilimler Dergisi, 2017; 1(2), 2564-7202.

20. McMillian, J. H., \& Schumacher, S. Research in Education: evidence-based inquiry. Pearson/Allyn and Bacon, 2006.

21. Nakip, M. Pazarlamada Araştırma Teknikleri. Seçkin Yayıncılık, 3, Ankara/ Türkiye, 2013.

22. Newzoo. Global Games Marketting Report An Overview Of Trends and Insights. Nisan 2017 tarihinde https://newzoo.com/insights/articles/global-gamesmarket-reaches-99-6-billion-2016-mobile-generating-37/ adresinden alınmıştır. 2016.

23. Newzoo. Global E-sports Marketting. Report Eylül 2018 tarihinde https://newzoo.com/insights/trendreports/global-esports-market-report-2018-light/ adresinden alınmıştır, 2018.

24. Özgün A, Yaşartürk F, Ayhan B. \& Bozkuş T. Examination of handball players levels of sports specific achievement motivation and happiness. Uluslararas1 Kültürel ve Sosyal Araştırmalar Dergisi, 2017; 3(2): 83-94.

25. Patton, M. Q. Nitel Çalışma ve Değerlendirme Yöntemleri. Pegem Yayıncılık. Ankara/ Türkiye 2014.

26. Pett, M. A., Lackey, N. R., \& Sullivan, J. J. Making Sense of Factor Analysis: The Use of Factor Analysis for Instrument Development in Health Care Research. Sage. 2003.

27. Uluslararası Çocuk ve Bilgi Güvenliği Etkinlikleri. Dijital Dünyada Rekabet. Dijital Oyunlar Çalıştayları. Ankara: 2017

28. Soyer F, Can Y, Güven H, Hergüner G, Bayansalduz M. \& Tetik B. Sporculardaki başarı motivasyonu ile takım birlikteliği arasındaki ilişkinin incelenmesi. Uluslararası Insan Bilimleri Dergisi, 2010; 7(1): 225-239.

29. Sun, Y. Motivation To Play Esports: Case of League of Legends. School of Hotel. Restaurant and Tourism Management. Calorina, 2017.

30. Tavşancıl, E. Tutumların Ölçülmesi ve Spss İle Veri Analizi. Ankara: Nobel Yayınevi 2014.

31. Tosun A., Demir B., Uçkun C. G. \& Konak O. Spor aktivitelerinin üniversite öğrencilerinin başarı ve motivasyonunu ile ilişkisi. Uluslararası Meslek Yüksekokulları Sempozyumu, 2015; 1-11. 
32. Tezbaşaran, A. A. Likert Tipi Ölçek Geliştirme Kılavuzu. Türk Psikologları Derneği Yayınları. Ankara/Türkiye, 2008

33. Warr, P. Esports in Numbers: Five Mind-blowing Stats. Nisan $2017 \quad$ tarihinde RedBull http://www.redbull.com/en/esports/stories/133164462838 9/esports-in-numbers-five-mind-blowing-stats adresinden alınmıştır, 2014

34. Witkowski, E. On the Digital playing Field: How we "Do Sport" With Networked Computer Games. Games and Culture. 2012; 7(5), 349-374.

35. Yıldırım, A., \& Şimşek, H. Sosyal Bilimlerde Nitel Araştırma Yöntemleri. Ankara: Seçkin Yayınları, 2011.

Participation Motivation Scale for E-Sports

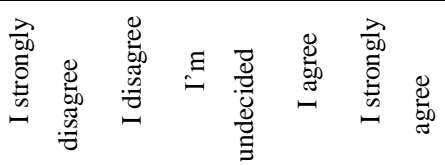

\begin{tabular}{ll}
\hline$(F 1)-1$ & It gives me pleasure to discover my talents in E-Sports. \\
\hline$(F 1)-2$ & The experiences I discovered in E-Sports give me pleasure. \\
\hline$(F 1)-3$ & It makes me happy to show my skills to others in E-Sports. \\
\hline$(F 2)-4$ & My friends' passion for E-Sports led me to E-Sports. \\
\hline$(F 2)-5$ & I got positive feedback from my environment after I started to do E-Sports. \\
\hline$(F 3)-6$ & I think doing E-Sports is enough for physical activity. \\
\hline$(F 1)-7$ & I like to follow professional players and teams in E-Sports. \\
\hline$(F 1)-8$ & E-Sports is a passion for me. \\
\hline$(F 1)-9$ & I am having a good time with my friends in E-Sports platform. \\
\hline$(F 3)-10$ & I'm playing E-sports to invest for the future. \\
\hline$(F 2)-11$ & I feel incomplete unless I do E-Sports. \\
\hline$(F 1)-12$ & The competitive environment in E-Sports excites me. \\
\hline$(F 3)-13$ & I think E-Sport is important for my health. \\
\hline$(F 1)-14$ & I value the friendship relationships I established in E-Sports. \\
\hline$(F 1)-15$ & I enjoy doing E-Sports in my spare time. \\
\hline$(F 1)-16$ & I like to know different people and cultures by doing E-Sports. \\
\hline$(F 3)-17$ & I feel more tired while doing E-Sports. \\
\hline$(F 2)-18$ & My family supports my interest in E-Sports and my being an E-Sports's athlete. \\
\hline$(F 1)-19$ & I enjoy the techniques and tactics in E-Sports. \\
\hline$(F 2)-20$ & I think E-Sports has positive effects on my education life. \\
\hline$(F 1)-21$ & I think E-sports is exciting in terms of content. \\
\hline$(F 1)-22$ & I enjoy making friends in the E-Sports platform. \\
\hline &
\end{tabular}

\section{E-Spor Katılım Motivasyon Ölçeği}

\begin{tabular}{ll}
\hline$(F 1)-1$ & E-Sporda yeteneklerimi keşfetmek bana haz veriyor. \\
\hline$(F 1)-2$ & E-Sporda keşfettiğim deneyimler bana haz veriyor. \\
\hline$(F 1)-3$ & E-Sporda yeteneklerimi başkalarına göstermek bana mutluluk veriyor. \\
\hline$(F 2)-4$ & Arkadaşlarımın E-Spor tutkuları beni E-Spora yönlendirdi. \\
\hline$(F 2)-5$ & E-Sporu yapmaya başladıktan sonra çevremden olumlu tepkiler aldım. \\
\hline$(F 3)-6$ & E-Spor yapmak, fiziksel aktivite için yeterli olduğunu düşünüyorum. \\
\hline$(F 1)-7$ & E-Sporda profesyonel seviyedeki oyuncu ve takımları takip etmekten hoşlanırım. \\
\hline$(F 1)-8$ & E-Spor yapmak benim için bir tutkudur. \\
\hline$(F 1)-9$ & E-Spor ortamında arkadaşlarımla iyi vakitler geçiyorum. \\
\hline$(F 3)-10$ & E-Sporu geleceğe yatırım yapmak için oynuyorum. \\
\hline$(F 2)-11$ & E-Spor yapmazsam kendimi eksik hissederim. \\
\hline$(F 1)-12$ & E-Spordaki rekabet ortamı beni heyecanlandırıor. \\
\hline$(F 3)-13$ & E-Sporun, sağlı̆̆ım için önemli olduğunu düşünüyorum. \\
\hline$(F 1)-14$ & E-Sporda kurduğum arkadaşlı ilişkilerime değer veriyorum. \\
\hline$(F 1)-15$ & Boş vakitlerimde E-Spor yapmaktan haz alıyorum. \\
\hline$(F 1)-16$ & E-Spor yaparak farklı kişi ve kültürleri tanımaktan haz alıyorum. \\
\hline
\end{tabular}




\begin{tabular}{ll}
\hline$(F 3)-17$ & E-Spor yaparken daha fazla yorulduğumu hissediyorum. \\
\hline$(F 2)-18$ & Ailem E-Spora ilgimi ve E-Sporcu olmamı destekliyor. \\
\hline$(F 1)-19$ & E-Spordaki teknik ve taktiklerden haz alıyorum. \\
\hline$(F 2)-20$ & E-Sporun eğitim hayatıma olumlu etkileri olduğunu düşünüyorum. \\
\hline$(F 1)-21$ & E-Sporlar içerik bakımından heyecan verici olduğunu düşünüyorum. \\
\hline$(F 1)-22$ & E-Spor ortamında arkadaş edinmekten zevk alıyorum. \\
\hline
\end{tabular}

